\title{
PHYSICAL PURITY AND GERMINATION OF SUGARCANE SEEDS (CARYOPSES) (Saccharum spp.) ${ }^{1}$
}

\author{
JULIANA TEREZINHA CAIEIRO ${ }^{2}$, MARISTELA PANOBIANCO ${ }^{3}$, JOÃO CARLOS BESPALHOK FILHO ${ }^{4}$, \\ OSVALDO DE CASTRO OHLSON ${ }^{5}$
}

\begin{abstract}
Plant breeding is generally done through sexual reproduction even when the species is propagated asexually for commercial exploitation, as for example, in sugarcane. Therefore, the development of procedures to evaluate sugarcane seed viability is important for plant breeding programs. The objective of this research was to develop a methodology for analyzing the viability of sugarcane seeds (Saccharum spp.). Three crosses were used, two biparental crosses and one polycross. For the germination test study, two substrates (paper and sand) and three constant incubation temperatures $\left(25^{\circ} \mathrm{C}, 30^{\circ} \mathrm{C}\right.$ and $\left.35^{\circ} \mathrm{C}\right)$, in the presence of constant light and also an alternating temperatures $\left(20-30{ }^{\circ} \mathrm{C}\right)$, with 8 hours light $\left(30^{\circ} \mathrm{C}\right)$ and 16 hours darkness $\left(20^{\circ} \mathrm{C}\right)$, were studied. Seedlings were evaluated every five days. The results demonstrated that temperature affected sugarcane seed germination with the most favorable conditions being the alternating temperature $\left(20-30{ }^{\circ} \mathrm{C}\right)$ and the constant temperature of $30^{\circ} \mathrm{C}$ on a paper substrate.
\end{abstract}

Index terms: substrate, temperature, plant breeding.

\section{PUREZA FÍSICA E GERMINAÇÃO DE SEMENTES (CARIOPSES) DE CANA-DE-AÇÚCAR (Saccharum spp.)}

RESUMO - O melhoramento de plantas geralmente é conduzido com o uso da reprodução sexuada, mesmo quando a espécie é multiplicada assexuadamente para a exploração comercial, como é o caso da cana-de-açúcar. Neste sentido, o desenvolvimento de procedimentos para avaliar a viabilidade de sementes de cana-de-açúcar é de grande interesse em programas de melhoramento genético. A pesquisa teve por objetivo o desenvolvimento de metodologia para avaliação da viabilidade de sementes de cana-de-açúcar (Saccharum spp.). Foram utilizadas três progênies, sendo duas provenientes de cruzamentos biparentais e uma progênie proveniente de policruzamento. Para o estudo do teste de germinação foram testados dois substratos (papel e areia), três temperaturas constantes de incubação $\left(25,30\right.$ e $\left.35^{\circ} \mathrm{C}\right)$, na presença de luz constante, e uma temperatura alternada $\left(20-30^{\circ} \mathrm{C}\right)$, com presença de luz por 8 horas $\left(30^{\circ} \mathrm{C}\right)$ e escuro por 16 horas $\left(20^{\circ} \mathrm{C}\right)$. As plântulas foram avaliadas em intervalos regulares de cinco dias. De acordo com os resultados obtidos, pode-se concluir que a temperatura interfere na germinação das sementes

${ }^{1}$ Subbmited on 08/07/2009. Accepted for publication on 20/04/2009. Parte da Dissertação de Mestrado do primeiro autor apresentada a UFPR.

${ }^{2}$ Bióloga, M.Sc., Laboratory of Official Seed Analysis-CLASP, jucaieiro@, yahoo.com.br.

${ }^{3}$ Eng. Agr.. Dr. Associate Professor, Departament of Crop and Phytoseiidae, UFPR, maristela@ufpr.br.
${ }^{4}$ Eng. Agr. Dr. Professor, Departament of Crop and Phytoseiidae, UFPR, bespa@ufpr.br.

${ }^{5}$ Eng. Agr., M.Sc., Laboratory Technician Responsible Official Seed Analysis-CLASP, osvaldodecastro@claspar.pr.gov.br. 
de cana-de-açúcar; sendo as condições mais favoráveis a alternância de temperatura $\left(20-30{ }^{\circ} \mathrm{C}\right)$ e a temperatura constante de $30^{\circ} \mathrm{C}$, em substrato papel.

Termos para indexação: substrato, temperatura, melhoramento.

\section{INTRODUCTION}

Sugarcane is a very important crop in Brazil and is grown on around 6,92 milion ha (CONAB, 2007). Most of the production is for the manufacture of sugar and alcohol and a smaller part is used to make distilled spirit and for cattle feed (Matsuoka et al., 2005). One of the main factors in the success of sugarcane in Brazil has been the development of breeding programs for more productive varieties adapted to different environments and resistant to various diseases.

Although sugarcane is a species which is propagated asexually for commercial exploitation, seed hybridization and production (caryopses) are essential for improvement. The basis of genetic improvement is the selection and cloning of superior progeny with segregated populations obtained by hybridizations (Cesnik and Miocque, 2004). Floral induction, the hybridizations and seed production in sugarcane occur only under specific conditions of temperature and photoperiod. In tropical regions, flowering occurs naturally whereas in sub-tropical and temperate regions, the photoperiod must be managed using growth chambers (Berding and Hurney, 2005).

Although the seeds are the principal source of genetic variability for sugarcane improvement, there are very few studies on their production and an analysis of their viability. Developing a method which can evaluate seed germination could help in determining the ideal harvesting point and result in obtaining material with a better physiological quality.

Due to the lack of information on the germinative power of sugarcane seed, more seeds are needed when sowing and since few seeds are produced by each hybridization, their potential wastage can result in the loss of promising material. Therefore, knowledge of seed viability is fundamental before starting plant production.

Standardized methodology is used for testing germination in many crop species and is described in the "Rules for Seed Analysis" (Brasil, 1992). However, for sugarcane, this test procedure is undescribed with no specifications on pure seed characteristics, substrate, temperature and test duration. Besides this, there are no detailed descriptions in the literature of the morphology of sugarcane seed or seedlings, which makes analyses in the seed laboratory more difficult.

Therefore, due to the importance of seed in the genetic improvement of sugarcane, the objective of the present study was to develop a methodology for evaluating sugarcane seed viability.

\section{MATERIALS AND METHODS}

The seeds used in the study were from sugarcane crosses carried out in the Serra do Ouro breeding station of the Federal University of Alagoas, located in the municipality of Murici - Alagoas, and belonging to the Program for Genetic Improvement of RIDESA, in April/ May, 2006. After harvest, the seeds were sent to the Seed Analysis Laboratory of CLASPAR (Product Classification Company of Paraná state), in Curitiba, Paraná state, where the study was done.

For the study, three sugarcane progenies were tested, two from biparental crosses (H64-1881 X RB91514 and RB91514 x H64-1881) and one progeny from the polycross (RB763710 x ?).

The characterization of the pure seed was done and based on this it was possible to determine the weight of the study sample for the analysis of purity. According to the Rules of Seed Analysis (Brasil, 1992), seeds smaller than normal, wrinkled, immature and starting to germinate, were considered normal, as long as they belonged to the same species, seed fragments and/ or broken dispersal units, but larger than half the original size; seeds attacked by diseases (but unaltered by the formation of sclerotia or charcoal rot), spikelet with glumes and a fertile floret (lemma and palea), containing a caryopsis, and bare caryopses of Poaceae without their glumes and florets (lemmas and paleas).

Once the pure seed was characterized, the test to determine the weight of 1,000 seeds could be done. For each lot of pure seed, eight sub-samples of 100 seeds were randomly separated and weighed on an analytical balance with a sensibility of $0.0001 \mathrm{~g}$. Due to the fact that the dispersal units of Saccharum spp. are not easily moved around, a manual separation method was used as described for this type of seed in the International Rules for Seed Analysis (ISTA, 2007), and the material from each progeny was tipped uniformly onto a table and mixed manually. This homogenized portion of seeds was then successively divided into two equal parts using a ruler until eight portions divided into two rows of four were obtained. From the combination of the $1^{\text {st }}$ and $3^{\text {rd }}$ 
portions of the $1^{\text {st }}$ row, with the $2^{\text {nd }}$ and $4^{\text {th }}$ portions of the $2^{\text {nd }}$ row, another lot was formed. By using the same procedure, a sub-sample was formed containing around 100 seeds for carrying out the test. After this, the weight of 1,000 seeds was calculated by multiplying the mean weight of the subsamples of 100 seeds by 10 , and a coefficient of variation of $\leq 6 \%$ was adopted (Brasil, 1992). With these results it was possible to calculate the minimum weight of the study sample so that it contained at least 2,500 seeds.

Four sub-samples, each of 25 seeds for each cross, and obtained from the lot of pure seeds, were used for the germination test, totaling 100 seeds per treatment (Figure 1). The seeds were sown in plastic boxes $(11.0 \times 11.0 \times 3.5 \mathrm{~cm})$ containing two types of substrates: paper and sand.

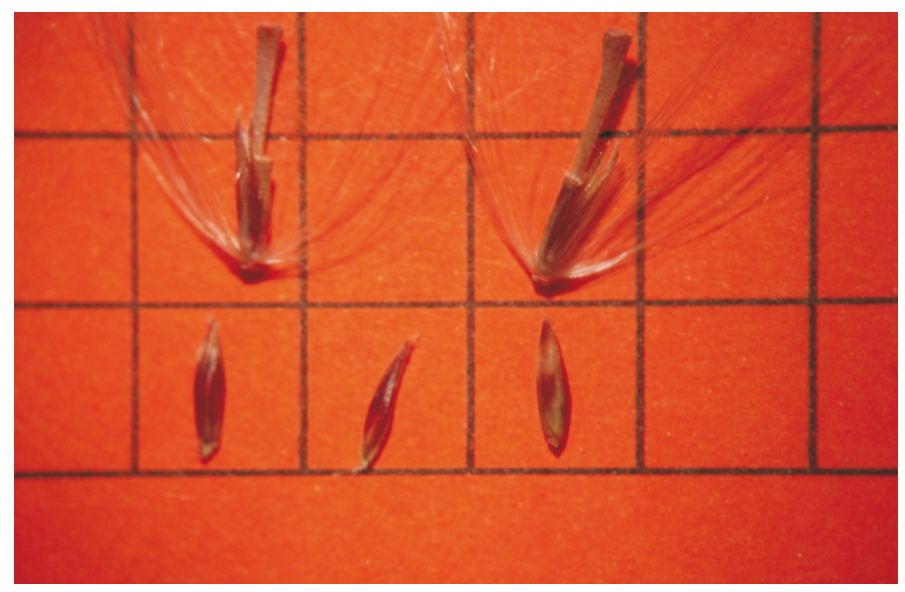

FIGURE 1. Batch of pure seed of Saccharum spp.

For the paper substrate, quantitative filter paper (10.5 $\mathrm{x} 10.5 \mathrm{~cm}$ ) with a grammage of $85 \mathrm{~g} \mathrm{~m}^{-2}$ was used, and four leaves were placed in each plastic box. The leaves were weighed and $10 \mathrm{~mL}$ of distilled water added to each repetition, which is a volume equivalent to 2.5 times the weight of dry substrate.

For the sand substrate, fine river sand normally used in building construction was used. It had been sterilized in an oven at $200{ }^{\circ} \mathrm{C}$ for two hours and $200 \mathrm{~g}$ of sand were used per repetition. The results of a granulometric test (Brasil, 1992) showed that $24 \mathrm{~mL}$ of water had to be added to each repetition.

Three constant incubation temperatures were tested $\left(25,30\right.$, and $\left.35^{\circ} \mathrm{C}\right)$, in the presence of constant light from fluoresecent lamps, in Mangelsdorf type germinators and an alternating temperature $\left(20-30^{\circ} \mathrm{C}\right)$, with $8 \mathrm{~h}$ light $\left(30^{\circ} \mathrm{C}\right)$ and $16 \mathrm{~h}$ darkness $\left(2^{\circ} \mathrm{C}\right)$, in a CASPMATIC G40 germinator.

The first count of normal seedlings was done on the 5th day after sowing and the final count after 15 days, with evaluations every five days when the normal seedlings were then removed (Figure 2).

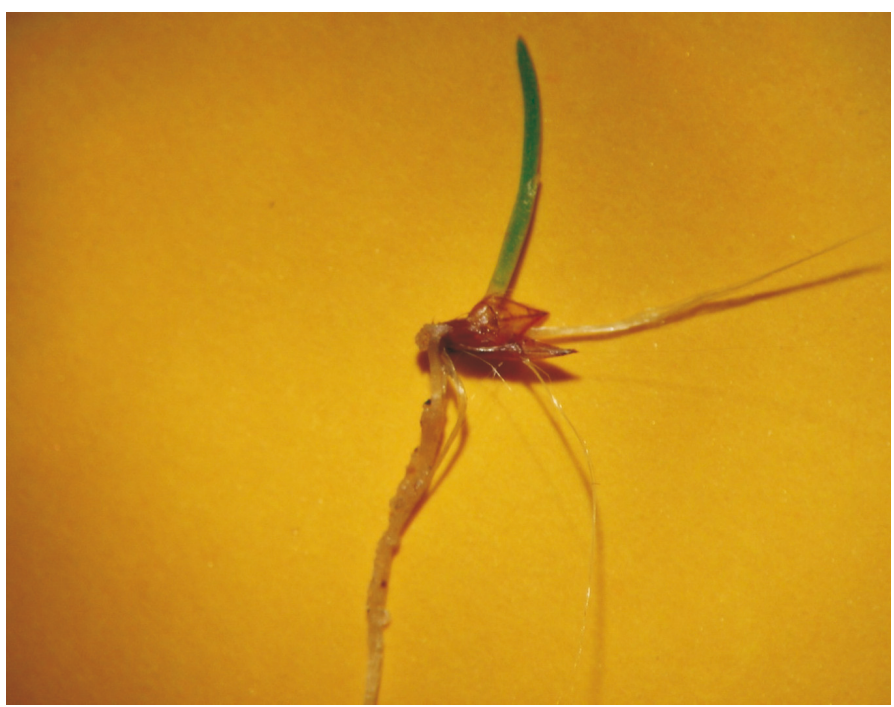

FIGURE 2. Normal seedling of Saccharum spp.

The experimental design was a completely random 2 $\mathrm{x} 4$ factorial, represented by two substrates (sand and paper) and four temperatures $\left(25,30,35\right.$ and $\left.20-30{ }^{\circ} \mathrm{C}\right)$, which were tested with the three progeny under study.

The homogeneity of the treatment variances was evaluated with Bartlett's test and data transformation was considered unnecessary. Treatment means were compared using the Tukey test at the $5 \%$ probability level. The data were analyzed using the MSTAT-C, Version 2.11 statistical program (Nissen, 1993).

\section{RESULTS AND DISCUSSION}

The following were considered as pure seed: spikelets with glumes sheathing the caryopsis, with the segment of the rachis and the pedicel, florets with lemma and palea wrapped round the caryopsis, with or without hairs, normally being present. Naked caryopses or parts of caryopses were not observed (Figure 1).

Considering that the sample weight for making the purity analysis had to contain at least 2,500 seeds (Brasil, 1992), the weight of the study sample for the progeny tested was calculated by multiplying the weight of 1,000 seeds for each progeny by 2.5 (Table 1 ). Based on the weight of 1,000 seeds from the three progeny studied, a work sample for sugarcane of approximately $2.0 \mathrm{~g}$ can be suggested, obtained 
by multiplying the weight of 1,000 seeds of the progeny with the heaviest seeds (RB763710 x ?) by 2.5 , and this makes sure that the sample does not have less than the 2,500 seeds necessary.

TABLE 1. Estimate of the weight of the study sample for the analysis of purity of three progeny of Saccharum spp.

\begin{tabular}{ccc}
\hline \multicolumn{1}{c}{ Progeny } & $\begin{array}{c}\text { Weight of } 1,000 \\
\text { seeds }(\mathrm{g})\end{array}$ & $\begin{array}{c}\text { Work sample for purity } \\
\text { analysis }(\mathrm{g})\end{array}$ \\
\hline H64-1881 x RB91514 & 0.470 & 1.175 \\
RB91514 x H64-1881 & 0.583 & 1.458 \\
RB763710 x ? & 0.686 & 1.715 \\
\hline
\end{tabular}

Both the substrate and the temperature are basic components of the germination test since the physiological response of seeds varies according to both these parameters (Stockman et al., 2007), and therefore, studying their effects on sugarcane seed germination is important.

The results from the Analysis of Variance showed significant differences for the temperature factor in the three progenies analyzed. Tables 2, 3 and 4 show the results of the germination of the progenies H64-1881 x RB91514, RB91514 $x$ H64-1881 and RB763710 x ?. There were no differences between the temperatures of $20-30{ }^{\circ} \mathrm{C}, 30^{\circ} \mathrm{C}$ and $35^{\circ} \mathrm{C}$ but the $25^{\circ} \mathrm{C}$ temperature had the worst performance. Besides having a smaller percentage of normal seedlings at $25^{\circ} \mathrm{C}$, germination was slower. Seedlings measured from 0.5 to $1.0 \mathrm{~cm}$, which when associated with the seed structure, resulted in a higher level of non-germinated and fungus-deteriorated seeds.

TABLE 2. Results of the seed germination test in sugarcane of the progeny H64-1881 $x$ RB91514, on two substrates and at four incubation temperatures.

\begin{tabular}{cccccc}
\hline \multirow{2}{*}{ Substrate } & \multicolumn{4}{c}{ Temperature $\left({ }^{\circ} \mathrm{C}\right)$} & MEAN \\
\cline { 2 - 5 } & 25 & 30 & 35 & $20-30$ & \\
\hline SAND & 7 & 13 & 15 & 13 & $12 \mathrm{a}$ \\
PAPER & 4 & 4 & 12 & 14 & $9 \mathrm{a}$ \\
\hline MEAN & $6 \mathrm{~B}$ & $9 \mathrm{AB}$ & $14 \mathrm{~A}$ & $14 \mathrm{~A}$ & \\
\hline
\end{tabular}

Means followed by the same capital letter in the row and the same small letter in the column are not different according to the Tukey test at the 5\% probability level.
TABLE 3. Results of the seed germination test in sugarcane of the progeny RB91514 $x$ H64-1881, on two substrates and at four incubation temperatures.

\begin{tabular}{lrrrrr}
\hline \multirow{2}{*}{ Substrate } & \multicolumn{4}{c}{ Temperature $\left({ }^{\circ} \mathrm{C}\right)$} & MEAN \\
\cline { 2 - 5 } & 25 & 30 & 35 & $20-30$ & \\
\hline SAND & 1 & 26 & 17 & 23 & $17 \mathrm{a}$ \\
PAPER & 3 & 12 & 19 & 14 & $12 \mathrm{a}$ \\
\hline MEAN & $2 \mathrm{~B}$ & $19 \mathrm{~A}$ & $18 \mathrm{~A}$ & $19 \mathrm{~A}$ & \\
\hline
\end{tabular}

Means followed by the same capital letter in the row and the same small letter in the column are not different according to the Tukey test at the 5\% probability level.

TABLE 4. Results of the seed germination test in sugarcane of the progeny RB763710 $x$ ?, on two substrates and at four incubation temperatures.

\begin{tabular}{lccccc}
\hline \multirow{2}{*}{ Substrate } & \multicolumn{4}{c}{ Temperature $\left({ }^{\circ} \mathrm{C}\right)$} & MEAN \\
\cline { 2 - 5 } & 25 & 30 & 35 & $20-30$ & \\
\hline SAND & 25 & 45 & 40 & 44 & $39 \mathrm{a}$ \\
PAPER & 30 & 35 & 37 & 49 & $38 \mathrm{a}$ \\
\hline MEAN & $28 \mathrm{~B}$ & $40 \mathrm{AB}$ & $39 \mathrm{AB}$ & $47 \mathrm{~A}$ & \\
\hline
\end{tabular}

Means followed by the same capital letter in the row and the same small letter in the column are not different according to the Tukey test at the 5\% probability level.

Statistical results were similar for the $30^{\circ} \mathrm{C}$ temperature and the $20-30{ }^{\circ} \mathrm{C}$ temperature and seedlings were betterdeveloped; however, alternating temperatures is inconvenient since it needs equipment with automatic temperature control or where the samples can be transferred daily to equipment with the two regulated temperatures (Brasil, 1992). Reliable automatic temperature control equipment for alternating temperatures is rarely found in seed analysis laboratories and doing this manually is difficult.

Although germination occurred at $35{ }^{\circ} \mathrm{C}$, the high temperature, associated with the high relative humidity inside the plastic boxes, caused burn-type lesions on the seedlings which made interpretation of the test difficult, principally for those seeds with a slower germination, which needed to be evaluated after the fifth day.

Figure 2 shows a normal sugarcane seedling with all the essential structures, including: seminal roots, coleoptile and plumule. 
In general, the maximum temperature for the seed germination of many species is in the range of 35 to $40{ }^{\circ} \mathrm{C}$ and optimum temperature between 15 and $30^{\circ} \mathrm{C}$ (Copeland, 1976). However, Marcos Filho (1986) and Borges and Rena (1993) observed that the 20 to $30^{\circ} \mathrm{C}$ range is adequate for the seed germination of tropical and sub-tropical species.

Cuenya et al. (1998) observed that the best temperature for the germination of sugarcane seeds occurred between 35 and $38^{\circ} \mathrm{C}$. However, Cesnik and Miocque (2004) declared that the ideal temperature for sugarcane seed germination is around $32{ }^{\circ} \mathrm{C}$, but no official temperature has been established.

The Rules for Seed Analysis (Brasil, 1992) recommend paper, cloth, sand or soil as substrates for the germination test. However, the substrates most used in the laboratory for this test are paper and sand. The preference for these two substrates is due to their characteristics, since factors such as aeration, structure, water retention capacity and the degree of disease infestation can vary according to the type of material used (Barbosa et al., 1985), and this would make standardization of the test difficult.

No statistical differences were observed between the sand and paper substrates used in this study for percentage germination of the three sugarcane progeny tested. However, due to the small seed size, compared to sand, paper is better because it is easier to handle and standardize in the laboratory.

The germination of the seeds of the sugarcane progenies tested was low, reaching a maximum value of $49 \%$. Cabral (2007), in a study of sugarcane seed germination at a temperature of $30{ }^{\circ} \mathrm{C}$, also found low percentages with a maximum of $59 \%$ of normal seedlings. According to this author, sugarcane is a species which forms few seeds and these have a low viability. Rao (1982), believes this occurs because, different from cereals which are selected for the greatest fertility with the aim of increasing seed production, sugarcane is selected for sterility since the flowering process reduces the amount of sugar stored in the stem.

Independently of the temperature and substrate tested, fully-developed seedlings were observed with an exposed plumule and a root system with various seminal roots. The abnormality observed was the presence of seedlings which, although they had a well-developed aerial part, had no roots.

Germination and full development of the three progenies tested occurred until the $10^{\text {th }}$ day and the tests were extended until the $15^{\text {th }}$ day although no germination was observed in this period. It is recommended that the counts for the sugarcane germination test be done on the 15th day after starting the test.

Substrate humidity was adequate during the test and there was no need to add water since the tests were done in germinators of the Mangelsdorf (constant temperatures) and CASPMATIC G40 (alternate temperatures) types, where the environmental relative humidity was close to $100 \%$. The seeds had also been placed inside plastic boxes (minichambers).

Figure 2 shows a normal sugarcane seedling with all the essential structures: seminal roots, coleoptile and plumule.

\section{CONCLUSION}

The alternation of temperatures $\left(20-30{ }^{\circ} \mathrm{C}\right)$ with a photoperiod is the best condition for testing the seed germination of sugarcane, followed by a constant temperature of $30^{\circ} \mathrm{C}$.

A paper substrate is the most recommended for doing the seed germination test for sugarcane.

\section{ACKNOWLEDGEMENTS}

Thanks to the Genetic Improvement Program of RIDESA, for providing all the seeds used in the study.

Thanks to the Seed Analysis Laboratory of CLASPAR for technical support and providing facilities to carry out the study.

\section{REFERENCIAS}

BARBOSA, J.M.F.; BARBOSA, L.M.M., PINTO, M.M. Influência do substrato, da temperatura e do armazenamento, sobre a germinação de sementes de quatro espécies nativas. Revista Brasileira de Sementes, v.10, n.1, p.46-54, 1985.

BERDING, N.; HURNEY, A.P. Flowering and lodging, physiological-based traits affecting cane and sugar yield: What do we know of their control mechanisms and how do we manage them? Field crops research, v.92, n.2/3, p.261275, 2005.

BORGES, E.E.L.; RENA, A.B. Germinação de sementes. In: AGUIAR, I.B.; PIÑA-RODRIGUES, F.C.M.; FIGLIOLIA, M.B. (Coord.) Sementes florestais tropicais. Brasília, DF: ABRATES, p.83-136, 1993.

BRASIL. Ministério da Agricultura e Reforma Agrária. Secretaria Nacional de Defesa Agropecuária. Departamento Nacional de Defesa Vegetal. Coordenação de Laboratório Vegetal. Regras para análise de sementes. Brasília, DF, 1992. 365p.

CABRAL, F.F. Qualidade fisiológica, determinação do teor de água e armazenamento de sementes de cana-deaçúcar provenientes de diferentes cruzamentos. 2007, 58f. 
Dissertação (Mestrado em Produção Vegetal) - Universidade Federal de Alagoas, Rio Largo, 2007.

CESNIK, R.; MIOCQUE, J.; Melhoramento da cana-deaçúcar, Brasília, DF: Embrapa Informação Tecnológica; Jaguariúna: Embrapa Meio Ambiente, 2004. 307p.

COMPANHIA NACIONAL DE ABASTECIMENTO CONAB. Central de informações agropecuárias: safras - cana. Disponível em <http://www.conab.gov.br>. Acesso em: 25 nov. 2007.

COPELAND, L.O. Principles of seed science and technology. Minnesota: Department of Crop and Soil Sciences Michigan State University, 1976. 369p.

CUENYA, M.I.; ROMERO, C.D.; CHAVANNE, E.R.; Producción de semilla botánica de caña de azúcar, In: Avance Agroindustrial, Tucumán, Ano 18, $n^{\circ}$ 72, março, 5 $-8,1998$.

INTERNATIONAL SEED TESTING ASSOCIATION ISTA. Seed vigour testing. In: ISTA. International rules for seed testing. Bassersdorf: ISTA, 2007. 46p.
MARCOS-FILHO, J. Germinação de sementes. In: CÍCERO, S.M.; MARCOS-FILHO, J.; SILVA, W.S. Atualização em produção de sementes. Piracicaba: Fundação Cargill, 1986. p.11-39.

MATSUOKA, S.; GARCIA, A.A.F.; ARIZONO, H. Melhoramento da cana-de-açúcar. In: BORÉM, L (Ed.). Melhoramento de espécies cultivadas. Viçosa: UFV, 2.ed, 2005, p.225-274.

NISSEN, O. MSTAT-C. A microcomputer for desing, management and analysis of agronomic research experiments. Version 2.11 East Lansing: Michigan State University, p.300, 1993.

RAO, P.S. Sugarcane seed storage for breeding and generic conservation. In: Seminário Inter Americano de la caña de azúcar - VARIEDADES. Flórida Internacional University. Miami. Usa, 1982.

STOCKMAN, A.L.; BRANCALION, P.H.S.; NOVEMBRE, A.D.L.C.; CHAMMA, H.M.C.P. Sementes de ipê-branco (Tabebuia róseo-alba (Ridl.) Sand. - Bignoniaceae): temperatura e substrato para o teste de germinação. Revista Brasileira de Sementes, v.29, n.2, p.121-125, 2007. 